\title{
Zinc and Magnesium Content in Human Teeth
}

\author{
Yoshiko Ishiwata and Masao Mishima \\ Department of Industrial Health, the Institute of Public Health, Tokyo \\ Hatsuko Kazama \\ Department of Chemistry, Tokyo Gakugei University, Tokyo \\ Takashi Hoshiai \\ Department of Public Health, Tokyo Medical College, Tokyo \\ Motoo Niwa \\ Department of Hygiene, Nippon Dental University, Tokyo
}

\section{INTRODUCTION}

The levels of trace metals to be found in human teeth have not yet been clearly established. Nor has there been any study of the relationship of metals to individual differences, age differences, sex, geographical factors or to differences between teeth in the same individual that are in various stages of odontogenesis. Information concerning the significance of metabolic and epidemiological factors is also negligible. The reason for this may be due to the many difficulties arising during the pretreatment of specimens and counter measures taken to prevent interference and inhibition from the other elements present in teeth, before accurate quantitative analysis can be performed. For the past several years, however, trace elements in teeth have begun to be considered as a potential index revealing the total amount of such elements injested by a subject since the initiation of odontogenesis until the time when the tooth is extracted as a specimen. In addition, recently checks of the degree of environmental pollution that affect the human body have been made by analyzing the metal content in teeth ${ }^{1 \sim 3}$.

With this in mind, dental specimens were separated into dentine and enamel components. Quantitative analyses ${ }^{4}$ were performed zinc and magnesium that are generally present in large quantities in these to determine the layers. Based on the results of volumetric analysis, concentration distributions and correlations among the metals were calculated.

\section{MATERIALS}

Dental specimens used in the analysis were obtained by extraction during odontorthosis. Extracted teeth were first premolars from a total of 50 boys and girls living in the Setagaya Ward in Tokyo. Table 1 shows the breakdown of the subjects by sex and age. Specimens were collected in the period between December 1977 and March 1978.

Table 1 Age distribution of subjects

\begin{tabular}{c|c|c|c|c|c|r|r|r}
\hline Age in years & 9 & 10 & 11 & 12 & 13 & 14 & 15 & $\begin{array}{c}\text { Total } \\
\text { by sex }\end{array}$ \\
\hline Male & 2 & 1 & 5 & 4 & - & - & - & 12 \\
Female & 2 & 13 & 12 & 6 & 1 & 2 & 2 & 38 \\
\hline Total by age & 4 & 14 & 17 & 10 & 1 & 2 & 2 & 50 \\
\hline
\end{tabular}


Reagents

Standard reagents for both magnesium and zinc were adjusted to a concentration of $1,000 \mathrm{ppm}$. This concentrate was diluted to the required concentrations.

Standard magnesium solution: 1 gram of pure magnesium (99\% and above) was dissolved in $100 \mathrm{~m} l$ of hydrochloric acid (diluted $1: 100$ ) and made up to 1 litre with distilled water to use as a concentrate.

Standard zinc solution: 1 gram of pure zinc (99.9\%) was dissolved in $50 \mathrm{ml}$ of hydrochloric acid (diluted $1: 3$ ) and made up to 1 litre with distilled water to use as a concentrate.

De-ionized water (hereafter referred to as "water"): Tap water was distilled in a Bursted-type distiller and passed twice through a mixed-bed ion exchange resin column for use in washing. Water was further distilled by a two-step quartz distillation method for use in microanalysis.

$20 \%$ calcium solution: 57.2 grams of calcium chloride was dissolved in $100 \mathrm{~m} l$ of water.*

Hydrochloric acid: Hydrochloric acid for heavy metal analysis was diluted to the required concentrations.

Reagents other than the above were all commercially obtained SSG, JIS special grade or those which would meet the JIS special grade for heavy metal analysis.

\section{Apparatus}

Vacuum freeze-dry asher: Model FDA-158, a fully automatic vacuum freeze-dry asher, manufactured by Yanagimoto Co., Ltd.

Atomic absorption spectrometer: Model AA-650, a double beam type atomic absorption spectrometer, manufactured by Shimazu.

Automatic pH adjuster: Model HS-2A, an automatic $\mathrm{pH}$ adjuster was attached to a model HM-5A pH meter, manufactured by Toa Dempa.

Pretreatment of Reagents and Method of Analysis

Dental specimens completely freed of contaminated material were washed in water and left in an air bath at $105-110^{\circ} \mathrm{C}$ for over 24 hours. After cooling to room temperature the

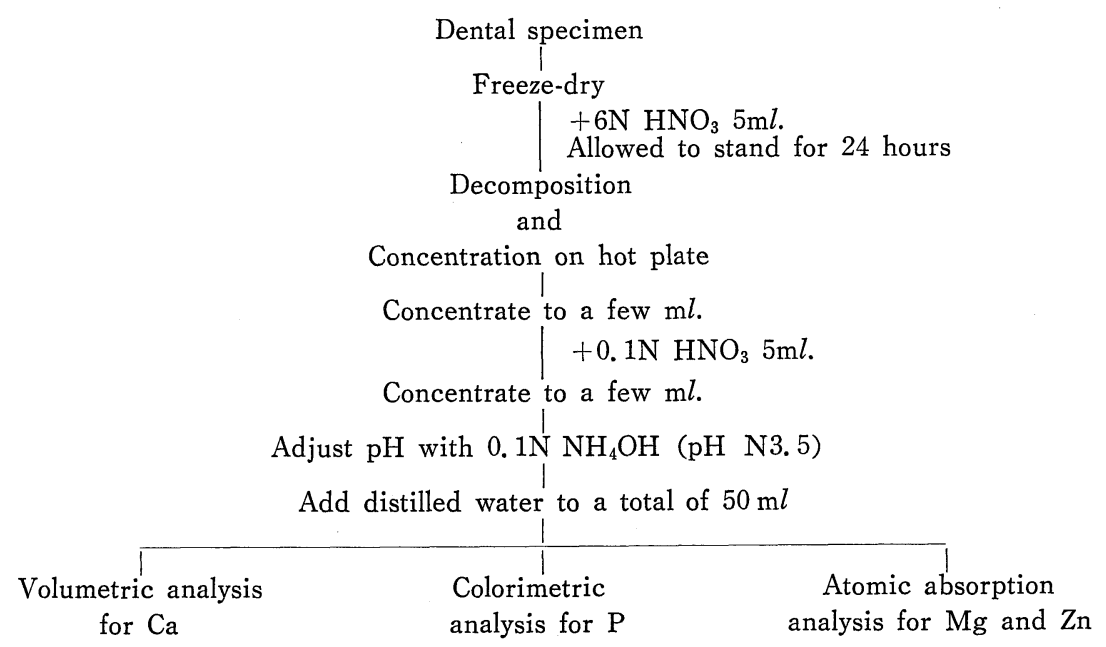

Chart 1 Pattern for the analysis of elements in human teeth

\footnotetext{
* The solubility of calcium chloride is 60 grams $-\mathrm{H}_{2} \mathrm{O}$ (at $20^{\circ} \mathrm{C}$ ). The solution, therefore, is nearly saturated.
} 
specimens were further dried in a vacuum freeze-dry asher. The dried specimens were mechanically ground and then separated into dentine and enamel components ${ }^{5}$. Each of them was precision weighted.

Specimens were placed in $20 \mathrm{~m} l$ beakers and left for 24 hours after adding $5 \mathrm{~m} l$ of $6 \mathrm{~N}$ nitric acid. The dental specimens were dissolved by condensation over heat and concurrently metals in the teeth were converted to nitrates. During this procedure, excess nitric acid in the reagent solution was removed by repeating the condensation procedure over heat, by adding dilute nitric acid $(0.1 \mathrm{~N}-0.5 \mathrm{~N})$. Next the $\mathrm{pH}$ was adjusted to $\simeq 3.5$ with a $0.1 \mathrm{~N}$ ammonium solution and the mixture was made up to $50 \mathrm{~m} l$ with water for use as the concentrated reagent in the metal analysis. Chart 1 shows schematically the pattern of the analysis. Quantitative analysis of zinc and magnesium was by atomic absorption spectrometry, that of calcium by gravity analysis $\left.{ }^{6}\right)$ and that of phosphoric acid by the Fiske-Sabbarow $\operatorname{method}^{7}$.

Metal concentrations are all expressed in terms of dry weight. Table 2 shows the analytical conditions during atomic absorption

Table 2 Analytical conditions of atomic absorption spectrometry

\begin{tabular}{|c|c|c|}
\hline & $\mathrm{Mg}$ & $\mathrm{Zn}$ \\
\hline Wavelength (nm) & 285.2 & 213.8 \\
\hline Lamp current $(\mathrm{mA})$ & 5 & 5 \\
\hline Slit width (nm) & 0.5 & 0.5 \\
\hline Air pressure $\left(\mathrm{kg} / \mathrm{cm}^{2}\right)$ & 1.5 & 1.5 \\
\hline Air flow rate $(1 / \mathrm{min})$. & 6. 0 & 6.0 \\
\hline Acetylene pressure $\left(\mathrm{kg} / \mathrm{cm}^{2}\right)$ & 0.5 & 0.5 \\
\hline Acetylene flow rate $(1 / \mathrm{min})$. & 1.0 & 1.0 \\
\hline
\end{tabular}
spectrometry.

Preparation of Analytical Curves by Means of Atomic Absorption Spectrometry

When dental specimens prepared by the wet-ashing method are analyzed directly, chemical interference occurs from the abundant calcium present in the specimens. Therefore, in order to avoid the influence of calcium and of the numerous other substances present in teeth, the necessary acids and bases must be added to the standard solution to reproduce a matrix that is equal to that of the speciments.

During quantitative metal analysis by atomic absorption spectrometry, if the measurement is made after calcium has been completely removed from the specimens, there is no need to use analytical curves prepared from some material with an equal matrix value. However, when large amounts of calcium are removed, trace metals present to the order of 1 microgram or less may also be lost due to co-precipitation. A satisfactory method to remove calcium rapidly from a multi-component specimen has not yet been developed.

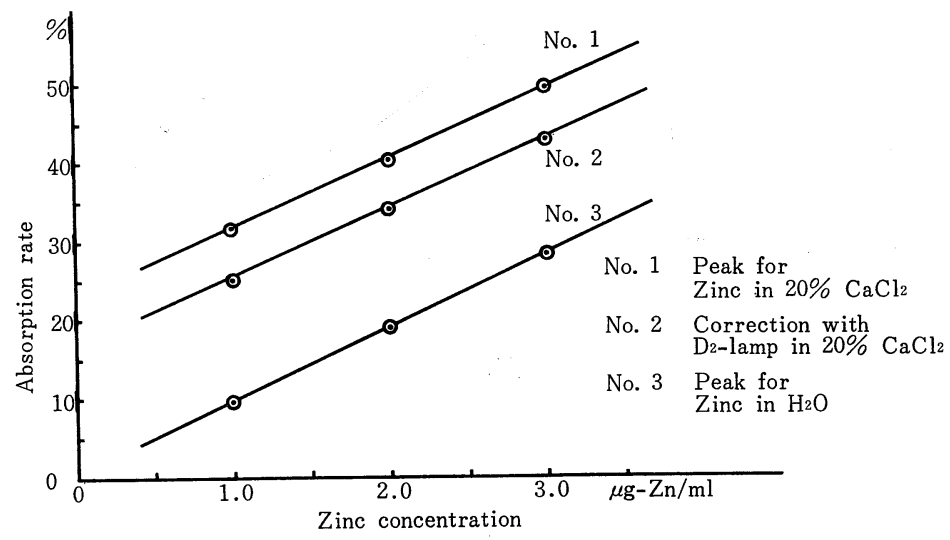

Fig. 1 Zinc calibration curve 
Accordingly in the present study standard solutions of metals were prepared with calcium concentrations $\left.^{8}\right)(35 \%)$ equivalent to the amount in teeth. In other words, pure metals were diluted to the required concentrations with a $20 \%$ calcium chloride solution as the solvent and these were used in plotting analytical curves. Analytical curves were plotted by using the measured values corrected for interference effects with a dutirium lamp.

Following the above procedure, extremely good results were obtained (Fig. 1). A similar experiment was conducted on chemical interference using phosphoric acid, but it was found that to have no effect on the quantitative analysis of magnesium and $z$ inc $^{9)}$.

\section{RESUlts}

The constituent ratios of dental and skeletal structures are usually expressed by indicating the ratio of calcium to phosphorus in addition to other constituent elements. Following this precedent, concentrations of calcium and phosphrus were also measured. The results of the quantitative analysis, inclusive of magnesium and zinc, are shown in Table 3. The table shows the maximum, minimum, mean, standard error and standard deviation values for each element. Furthermore, for magnesium and zinc, frequency distribution charts

Table 3 Analysis of selected elements in teeth

\begin{tabular}{l|c|c|c|c|c|c|c}
\hline & Element & No. $^{1)}$ & Max. $^{2)}$ & Min. $^{3)}$ & Mean & S.E. ${ }^{4)}$ & S.D.5) \\
\hline \multirow{5}{*}{ ENAMEL } & $\mathrm{Mg}^{6)}$ & 47 & 4,200 & 3,700 & 4,000 & 200 & 1,280 \\
& $\mathrm{Zn}^{6)}$ & 48 & 345 & 140 & 219 & 18 & 44 \\
& $\mathrm{Ca}^{7)}$ & 48 & 41.76 & 34.55 & 33.45 & 0.71 & 4.95 \\
& $\mathrm{P}^{7)}$ & 48 & 19.62 & 15.38 & 17.78 & 0.11 & 0.73 \\
\hline \multirow{5}{*}{ DENTINE } & $\mathrm{Mg}^{6)}$ & 47 & 8,600 & 8,200 & 8,400 & 50 & 100 \\
& $\mathrm{Zn}^{6)}$ & 47 & 142 & 19 & 50 & 18 & 23 \\
& $\mathrm{Ca}^{7)}$ & 50 & 28.60 & 25.40 & 26.47 & 0.21 & 1.46 \\
& $\mathrm{P}^{7)}$ & 48 & 14.66 & 10.13 & 12.34 & 0.13 & 0.88 \\
\hline
\end{tabular}

1) Number of samples 2) Maximum value 3) Minimum value 4) Standard error

5) Standard deviation 6) Unit: $\mu \mathrm{g} / \mathrm{g}$ (Dry weight) 7) Unit: \%

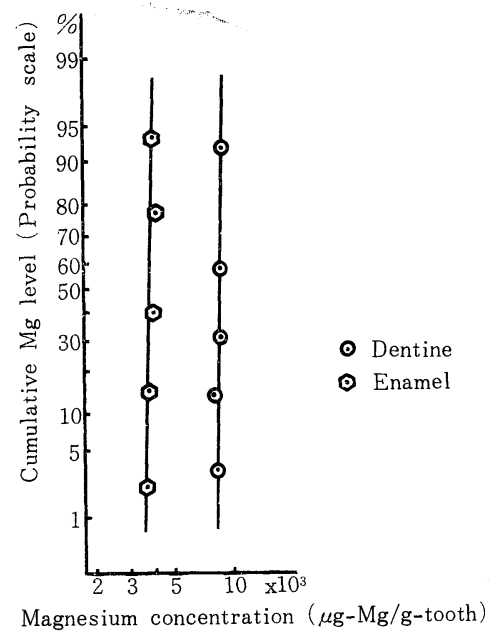

Fig. 2 Cumulative frequency of magnesium

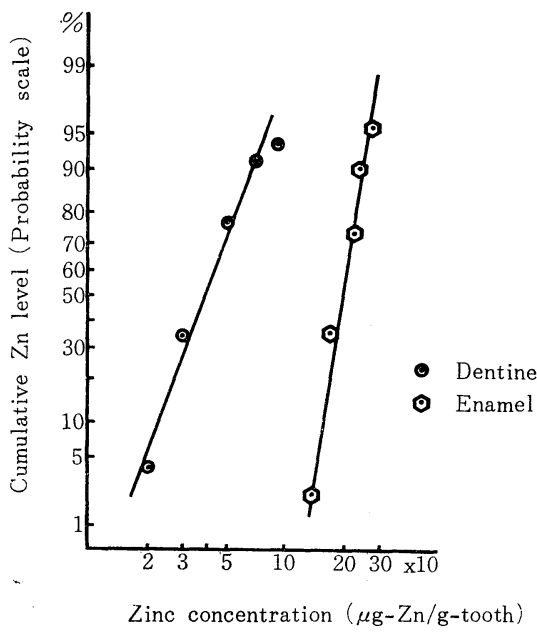

Fig. 3 Cumulative frequency of Zinc 
have been prepared for enamel and dentine based on which the results were plotted on normal logarithmic probability sheets which are shown as Fig. 2 and 3. The results from the measurement of magnesium and zinc will be examined first.

\subsection{Magnesium}

Magnesium is an metal essential to the human body and it is a representative enzyme active metal. It is particularly noted for high activity in reaction to enzymes with a phosphate bond ${ }^{10)}$. Thus, when such enzymes are incorporated into the soft tissue of the odontoblast, a large quantity of magnesium is believed to mix in. It works antagonistically to calcium ions, and thus the magnesium level rises with a drop in the calcium ion concentration. In view of such chemical behavior, therefore, the magnesium content in teeth is thought to be high.

Magnesium concentrations found in the teeth used in the present experiment were as follows;

$\begin{array}{ll}\text { Enamel } & 4,000 \pm 1,280 \mu \mathrm{g}-\mathrm{Mg} / \mathrm{g} \\ \text { Dentine } & 8,400 \pm 100 \mu \mathrm{g}-\mathrm{Mg} / \mathrm{g}\end{array}$

As is clear from Fig. 2 the range was narrow and the distribution was lognormal. From the concentration distribuitions of magnesium in enamel and dentine which were approximately symmetrical, it has been estimated that the magnesium concentration ratios in the two layers are comparatively constant. Moreover, there seems to be little magnesium metabolism in teeth so that the magnesium balance is more or less constant from the initial stages of odontogenesis.

\section{2 Zinc}

Zinc is another metal essential to the body and is one of the elements that is found in abundance in teeth. Zinc is known to compete with calcium on the sedimentation site on the surface of apatite ${ }^{11}$. It elevates the acid resistance of hydroxy-apatite $\left[\mathrm{Ca}_{10}\left(\mathrm{PO}_{4}\right)_{6}\right.$ $\left.(\mathrm{OH})_{2}\right]^{12)}$. Consequently, zinc content in teeth is the highest of all metals, and is particularly high in tooth enamel. The results of the measurement in the present study are as follows;

$$
\begin{array}{lr}
\text { Enamel } & 219 \pm 44 \mu \mathrm{g}-\mathrm{Zn} / \mathrm{g} \\
\text { Dentine } & 50.5 \pm 23.8 \mu \mathrm{g}-\mathrm{Zn} / \mathrm{g}
\end{array}
$$

Compared to enamel, the concentration range of zinc in the dentine was broader (Fig. 3 ). Furthermore, the concentration distribution was lognormal for both layers, but the two zinc distributions were not parallel as true for magnesium. Hence, it is assumed that the behavior of zinc in enamel and in dentine differs.

\section{3 Correlation of Metals}

Some investigators may feel that judgments based on correlation coefficients should not be given a central role in an experimental study. However, others feel that coefficients obtained by statistical data processing may represent important information.

In the present study correlations were obtained from the analysis of magnesium and zinc as well as from the calcium to phosphorus ratio. Due to the small sample and because the correlation obtained was a simple correlation, the results are poor. The following consideration was made with this taken into account.

There was no correlation found between zinc and magnesium. However, a high correlation was observed between magnesium and zinc in relation to $\mathrm{Ca} / \mathrm{P}$, and in the magnesium concentration in the enamel and dentine ${ }^{13)}$.

Fig. 4 shows the correlation between $\mathrm{Ca} / \mathrm{P}$ and $\mathrm{Mg}$. The correlation was the linear regression; 


$$
\begin{array}{lcc}
\mathrm{y}=0.13 \mathrm{x}+1.61 & \mathrm{n}=44 & \gamma=0.378 \\
\text { (significant with a risk of } 5 \% \text { ) } &
\end{array}
$$

In addition, for $\mathrm{Ca} / \mathrm{P}$ and $\mathrm{Zn}$, the figures obtained were as follows;

$$
\begin{aligned}
& \mathrm{y}=0.09 \mathrm{x}+1.91 \quad \mathrm{n}=45 \quad r=0.358 \\
& \text { (significant with a risk of } 10 \% \text { ) }
\end{aligned}
$$

The regression line is shown in Fig. 5.

Comparing the above results the two regression lines were found to have a similar

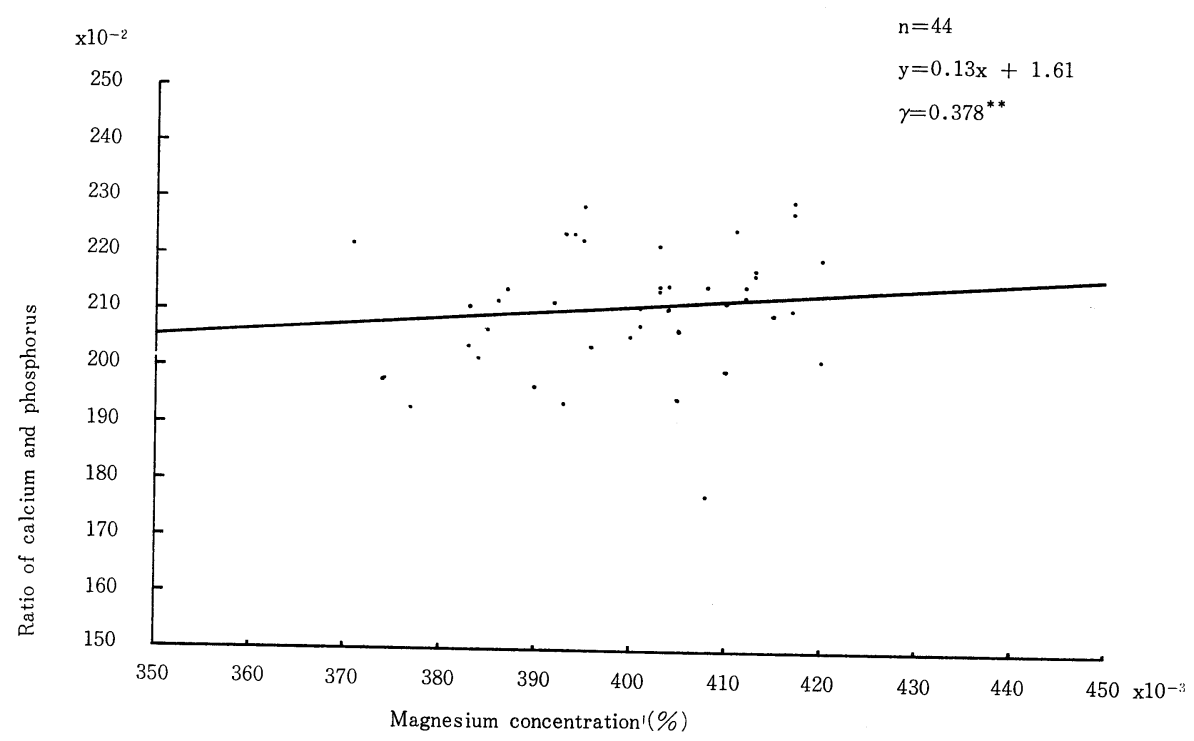

Fig. 4 Regression point between $\mathrm{Mg}$ and $\mathrm{Ca} / \mathrm{P}$ in enamel

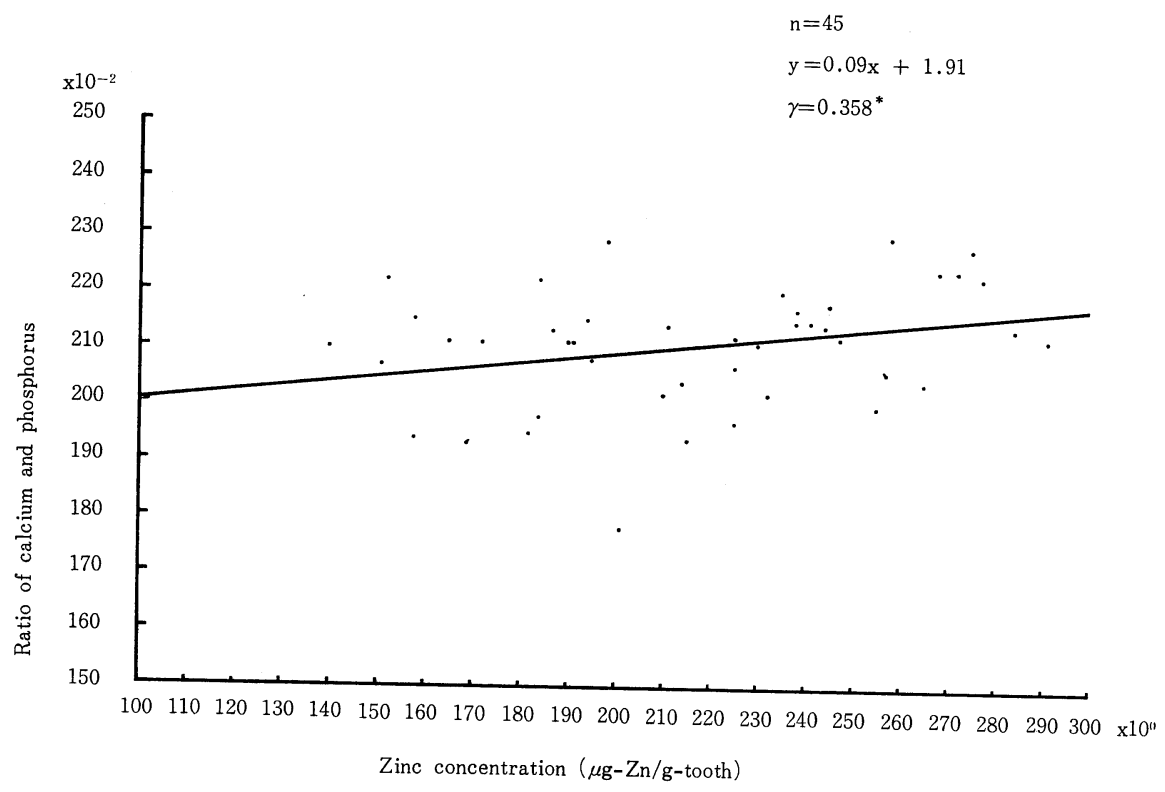

Fig. 5 Regressinon point between $\mathrm{Zinc}$ and $\mathrm{Ca} / \mathrm{P}$ in enamel 
gradient. Thus magnesium and zinc possess some similarity in given functions (enzyme reaction systems and $\mathrm{Ca}$ reaction systems for example) as opposed to $\mathrm{Ca} / \mathrm{P}$. It has been theorized that magnesium and zinc are each dependent on calcium or phosphorus when teeth are first developing. A correlation, however, was not obtained between magnesium and zinc, therefore, it is assumed that there is no common reaction system or dependent behavior common to both.

Fig. 6 shows the correlation of magnesium concentrations between enamel and dentine. The correlation was observed as a linear regression indicating an extremely large correlation coefficient as shown below;

$$
\begin{array}{lcc}
\mathrm{y}=1.33 \mathrm{x}-71.82 & \mathrm{n}=45 & \gamma=0.877 \\
\text { (significant with a risk of } 1 \% \text { ) } &
\end{array}
$$

This indicates that magnesium is an enzyme-active metal in teeth and that in both enamel and the dentine, behaves in the same manner.

In contrast, zinc competes with calcium in the enamel layer, in view of the small deposition of zinc in dentine, a correlation was not observed for zinc between enamel and dentine. This tendency was observed in the concentration distribution pattern as well (Figs. 3 and 4 ).

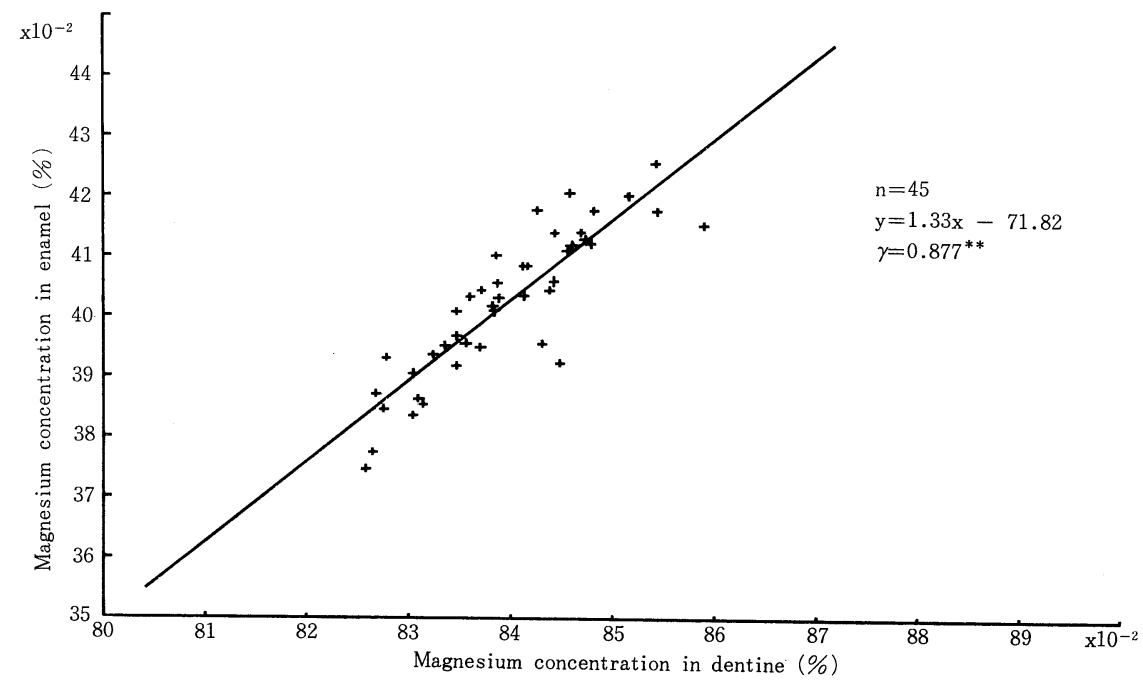

Fig. 6 Regression point of magnesium between enamel and dentine

\section{CONCLUSIONS}

In the past, there have been various reports of several metal concentrations contained in teeth ${ }^{14,15)}$, however, very little consideration has been given to the interference and inhibition of calcium and phosphates that are also found in large amounts. Accordingly, the accuracy of analytical results have been questioned and experimental results have shown wide variations.

After thorough study of previous analytical methods employed, the authors made quantitative analysis of the zinc and magnesium contained in human teeth. On the basis of the results obtained, the range of normal values was estimated chemically to show maximum and minimum values. It is obvious that by determining the upper limits of normal 
values, one may define that may be considered "abnormal" and ultimately provide invaluable information for diagnosis of dental health problems and their effects on the human body. Concentration distributions were also obtained from the measurements. Correlations between the metals have been graphed. However, as specimens were obtained from a single geographical region and as the numbers analyzed were only 50 in total, obviously it is difficult to conclude that the result are "standard values". Nevertheless, the authers feel that the results reveal a certain trend in the concentration distribution and correlations of zinc and magnesium.

\section{1) Method of Analysis}

For the purposes of this experiment, favorable results were obtained by using a standard solution prepared with $20 \%$ calcium chloride as the solvent and plotting analytical curves.

\section{2) Concentration Distribution}

Concentration distribution patterns of both magnesium and zinc showed a normal logarithmic distribution. Furthermore, the concentration distribution patterns of magnesium in enamel and dentine were very similar, however, such a tendency was not observed for zinc.

3) Correlations

$\mathrm{Ca} / \mathrm{P}$ and magnesium correlated highly while that of $\mathrm{Ca} / \mathrm{P}$ to zinc was low. In particular, magnesium showed an extremely high correlation with both enamel and dentine.

Acknowledgement: The authors are greatly indebted to Professor J. Miyazawa of Tokyo Medical Colledge and Mr. T. Daimon of Shimazu Seisakusho Ltd. who have given unending guidance in conducting the present study.

\section{REFERENCES}

1) Langmyhr, F. J. and Sundli, A.: Atomic absorption spectrometric determination of cadmium and lead in dental material by atomization directly from the solid state, Analytica Chim. Acta, 73, 81 (1974).

2) Dolinsek, F., Stupar, J. and Spenko, M.: Determination of alminium in dental enamel by the carbon cup atomic-absorption method, Analyst, 100, 884 (1975).

3) Handelman, S. L. and Losee, F. L.: Inhibition of enamel solubility in a highly mineralized water, Talanta, 50, 1605 (1971).

4) Kaneko, Y.: The natural occurence of trace metals in human teeth (I), J. Oral Hygiene, 21 (3), 53 (1971).

5) Niwa, M.: Manuscript to be submitted to the Journal of Oral Hygiene.

6) Kimura, K.: Inorganic Volumetric Analysis, p. 263 Kyoritsu Shuppan, Tokyo (1955).

7) Fiske, C. H. and Subbarow, Y.: The colorimetric determination of phosphorus, J. Biol. Chem., 66, 375 (1925).

8) Lazzari, E. P.: Dental Biochemistry, p. 15, Lee \& Febriger, Philadelphia (1968).

9) Helsby, C. A.: Determination of strontium in human tooth enamel by flameless atomic-absorption spectrometry, Talanta, 24, 46 (1977).

10) Bower, H. J. M.: Trace Elements in Biochemistry, p. 123 Academic Press, London (1966).

11) Cruickshank, D. B.: The frequency distribution of zinc concentrations in the dental tissues of the normal population, J. Biochem., 44, 299 (1949).

12) Mori, M., Yoshida, W., Mizushima, T. and Amatsu, N.: Histochemical observation of phosphatase and nucleotidase of the developing teeth, Arch. Hist. Jap., 20, 519 (1960).

13) Kaneko, Y.: The natural occurrence of trace metals in human teeth (II), J. Oral Hygiene, 22 (1), 79 (1972).

14) Shapiro, I. M., Needleman, H. L. and Tuncay, O. C.: The lead content of human deciduous and permanent teeth, Environmental Research, 5, 467 (1972).

15) Brudevold, F., Steadman, L. T., Spinelli, M. A., Amdur, B. H. and Gron, P.: A study of zinc in human teeth, Arch. Oral Biol., 8, 135 (1963). 


\title{
人歯牙中の亜鉛およびマグネシウム含有量
}

\author{
石 渡 淑 子. 三島 昌 夫 \\ 国立公衆衛生院労衝衛生部 \\ 風 間 発子 \\ 東京学芸大学化学教室 \\ 星 合 尚 \\ 東京医科大学公衆衛生学教室 \\ 丹羽源 男 \\ 日本歯科大学衛生学教室
}

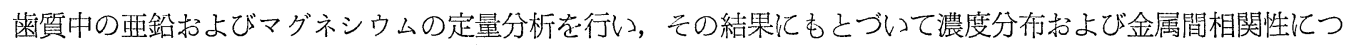
いて検討した。その結果次のような傾向を把握した。

1）分析方法

䨑質中のマグネシウムおよび亜鉛の定量分析を行うかぎりにおいては，20\%塩化カルシウム溶液を溶媒とした 標準溶液を調製し，検量線を作成して定量分析を行うことにより，良好な結果を得た。

2) 濃度分布

マグネシウムおよび亜鉛の濃度分布型は，いずれも対数正規分布を示した。

また，エナメル質および象牙質中のマグネシウムの濃度分布型は酷似したが，业鉛にはそのような傾向はみら れなかった。

3）相関性

$\mathrm{Ca} / \mathrm{P}$ とマグネシウムとの相関は高く，亜鉛との相関は低い結果を示した。とくにマグネシウム濃度は，エナ メル質および象牙質間で極めて高い相関性を示した。

（受付 1979年 4 月19日） 